\title{
PENGARUH MODEL PEMBELAJARAN INSIDE OUTSIDE CIRCLE BERORIENTASI KEARIFAN LOKAL TERHADAP HASIL BELAJAR MATEMATIKA SISWA KELAS V
}

\author{
${ }^{1}$ Gusti Ayu Novi Ariasih, ${ }^{2}$ I Made Suarjana, ${ }^{3}$ Gede Wira Bayu \\ ${ }^{1,2,3}$ Prodi Pendidikan Guru Sekolah Dasar, Universitas Pendidikan Ganesha \\ e-mail: ayunoviariasih@gmail.com, suarjana_undiksha@yahoo.co.id. \\ wira.bayu@undiksha.ac.id
}

\begin{abstract}
Abstrak
Tujuan dari penelitian ini adalah untuk mengetahui pengaruh model pembelajaran Inside Outside Circle berorientasi kearifan lokal terhadap hasil belajar matematika pada siswa SD kelas V Gugus I Kecamatan Buleleng. Jenis penelitian ini adalah penelitian eksperimen semu dengan desain post test only control group design. Populasi penelitian ini adalah seluruh kelas V SD di Gugus I Kecamatan Buleleng yang berjumlah 214 orang. Penentuan sampel menggunakan teknik group random sampling. Pengumpulan data dalam penelitian ini dilakukan dengan menggunakan metode tes. Instrumen pengumpulan data yang digunakan berupa tes objektif dengan teknik pilihan ganda. Data yang dikumpulkan dianalisis menggunakan analisis statistik deskriptif dan inferensial dengan teknik uji-t independent. Hasil penelitian menunjukkan terdapat pengaruh yang signifikan model pembelajaran Inside Outside Circle berorientasi kearifan lokal terhadap hasil belajar matematika pada siswa SD kelas V gugus I Kecamatan Buleleng.
\end{abstract}

Kata-kata kunci: Inside Outside Circle, Hasil Belajar Matematika, kearifan lokal

\begin{abstract}
The purpose of this study was to find out the influence of the local wisdom oriented Inside Outside Circle learning model on mathematics learning outcomes in elementary school students in class V of Cluster I, Buleleng district, 2018/2019 academic year. The type of this research was a quasi-experimental study with a post-test only control group design. The population of this study was all class $\mathrm{V}$ elementary schools in Cluster I of Buleleng district which were 214 people. This research used group random sampling technique. Data collection in this study was carried out using the test method. The instruments of data collection used were objective tests with multiple choice techniques. Data collected was analyzed using descriptive and inferential statistical analysis with independent t-test techniques. The results showed that there was a significant influence on the local wisdom oriented Inside Outside Circle learning model towards the mathematics learning outcomes of elementary school students in class $\mathrm{V}$ cluster I, Buleleng district.
\end{abstract}

Keywords: Inside Outside Circle, local wisdom, Mathematic Learning Achievment

\section{PENDAHULUAN}

Matematika merupakan salah satu ilmu pengetahuan yang sangat memegang peranan penting, sehingga perlu mendapat perhatian, terutama dalam kehidupan sehari-hari tidak terlepas dari kegiatan yang membutuhkan matematika mulai dari yang sederhana hingga yang kompleks. Menurut Susanto (2013) matematika menjadi pokok materi penting 
yang dapat membantu perkembangan industri dan teknologi. Pembelajaran matematika dirancang untuk mengajak siswa mampu mengembangkan berpikir kritis, logis, kreatif, analitis dan sitematis dalam menyelesaikan suatu permasalahan yang ada, dan nantinya siswa dapat mengkomunikasikan cara yang digunakan untuk memecahkan masalah tersebut. Pendapat tersebut didukung oleh, Japa dan Suarjana, (2015:3) mengatakan, "mata pelajaran matematika perlu diberikan kepada semua peserta didik terutama di sekolah dasar untuk membekali siswa dengan "kemampuan untuk memperoleh, memilih dan mengelola informasi membutuhkan pemikiran yang logis, analitis, sistematis, kritis dan kreatif".

Namun pada kenyataannya hasil belajar matematika siswa masih jauh dari harapan, hal ini dapat dilihat dari data hasil PISA. Pada pelaksanaan PISA tahun 2015 hasil belajar siswa Indonesia pada konten matematika menunjukkan hasil yang belum memuaskan dari pada konten membaca dan sains (Kemendikbud, 2015). Selain itu dilihat dari hasil pencatatan dokumen tabel nilai rata-rata hasil ulangan umum semester I mata pelajaran matematika siswa kelas V di Gugus I Kecamatan Buleleng seperti pada tabel 1 berikut.

Tabel 1. Nilai rata-rata hasil ulangan umum semester I mata pelajaran matematika siswa kelas V di Gugus I Kecamatan Buleleng.

\begin{tabular}{|c|c|c|c|c|c|c|c|c|}
\hline \multirow[t]{2}{*}{ No. } & \multirow{2}{*}{$\begin{array}{l}\text { Nama } \\
\text { Sekolah } \\
\text { Dasar }\end{array}$} & \multirow[t]{2}{*}{ Kelas } & \multirow[t]{2}{*}{ KKM } & \multirow[t]{2}{*}{$\begin{array}{c}\text { Jumlah } \\
\text { siswa }\end{array}$} & \multicolumn{2}{|c|}{$\begin{array}{c}\text { Jumlah Siswa } \\
\text { Mencapai } \\
\text { KKM }\end{array}$} & \multicolumn{2}{|c|}{$\begin{array}{c}\text { Jumlah Siswa } \\
\text { Belum Mencapai } \\
\text { KKM }\end{array}$} \\
\hline & & & & & SISWA & $\%$ & SISWA & $\%$ \\
\hline 1. & $\begin{array}{c}\text { SDN } 1 \\
\text { Banyuning }\end{array}$ & $\mathrm{V}$ & 65 & 41 & 6 & 14.63 & 35 & 85.37 \\
\hline 2. & $\begin{array}{c}\text { SDN } 2 \\
\text { Banyuning }\end{array}$ & V & 67 & 36 & 10 & 27.78 & 26 & 72.22 \\
\hline 3. & $\begin{array}{c}\text { SDN } 3 \\
\text { Banyuning }\end{array}$ & V & 70 & 30 & 5 & 16.67 & 25 & 83.33 \\
\hline 4. & $\begin{array}{c}\text { SDN } 5 \\
\text { Banyuning }\end{array}$ & $\begin{array}{l}\text { VA } \\
\text { VB }\end{array}$ & $\begin{array}{l}70 \\
70\end{array}$ & $\begin{array}{l}22 \\
20\end{array}$ & $\begin{array}{l}5 \\
5\end{array}$ & $\begin{array}{l}22.73 \\
25.00\end{array}$ & $\begin{array}{l}17 \\
15\end{array}$ & $\begin{array}{l}77.27 \\
75.00\end{array}$ \\
\hline 5. & $\begin{array}{c}\text { SDN } 6 \\
\text { Banyuning }\end{array}$ & $\mathrm{V}$ & 65 & 24 & 8 & 33.33 & 16 & 66.67 \\
\hline 6. & $\begin{array}{c}\text { SDN } 8 \\
\text { Banyuning }\end{array}$ & $\begin{array}{l}\text { VA } \\
\text { VB }\end{array}$ & $\begin{array}{l}70 \\
70\end{array}$ & $\begin{array}{l}21 \\
20\end{array}$ & $\begin{array}{c}12 \\
8\end{array}$ & $\begin{array}{l}57.14 \\
40.00\end{array}$ & $\begin{array}{c}9 \\
12\end{array}$ & $\begin{array}{l}42.86 \\
60.00\end{array}$ \\
\hline & Jumlah & & & 214 & 59 & & 155 & \\
\hline
\end{tabular}

Berdasarkan Tabel 1. persentase nilai ulangan akhir semester memperlihatkan bahwa hasil belajar matematika siswa kelas $\mathrm{V}$ masih belum maksimal, karena rata-rata persentase siswa yang belum mencapai KKM yaitu 70,34\% lebih banyak dari pada rata-rata persentase siswa yang mencapai KKM yaitu 29,66\%. Dengan kata lain lebih banyak siswa yang belum tuntas dari pada siswa yang tuntas.

Hasil observasi dengan guru matematika di salah satu sekolah, pembelajaran di kelas kurang menuntut siswa untuk meningkatkan hasil belajarnya. Hal ini disebabkan beberapa hal yaitu: 1) pembelajaran di kelas masih dominan menggunakan metode ceramah, 2) kurang bervariasinya model dalam proses pembelajaran matematika, 3) kurang motivasi dan minat siswa dalam pembelajaran matematika, 4) rendahnya partisipasi siswa dalam bertanya dan menjawab pertanyaan saat pembelajaran berlangsung, 5) belum memanfaatkan lingkungan sekitar dalam proses pembelajaran. Selain itu, rata-rata nilai 
matematika siswa pada sekolah-sekolah yang dijadikan populasi juga masih tergolong rendah.

Memperhatikan uraian permasalahan, untuk itu hendaknya guru mampu mewujudkan pembelajaran yang sesuai dengan karakteristik abad 21 yakni upaya meningkatkan mutu pendidikan. Hosnan (2014) mengatakan, strategi pembelajaran yang diimplementasikan guru di dalam kelas harus mempunyai beberapa karakteristik antara lain (1) (student centered), (2) mengembangkan kreativitas peserta didik, (3) menciptakan suasana yang menarik, menyenangkan, dan bermakna, (4) mengembangkan beragam kemampuan yang bermuatan nilai dan makna, (5) peserta didik aktif berbuat, (6) menekankan pada penggalian, penemuan dan penciptaan (7) pembelajaran dalam situasi nyata kontekstual. Rafianti (2018) mengemukakan, pembelajaran yang berpusat pada siswa memiliki beberapa karakter yang sering disebut 4C yaitu, 1) communication, peserta didik dituntut untuk memahami, mengelola, dan menciptakan komunikasi yang efektif dalam berbagai bentuk isi secara lisan, tulisan dan multimedia, 2) collaboration, artinya pada proses pembelajaran guru hendaknya menciptakan situasi dimana peserta didik dapat belajar bersama-sama atau berkelompok, 3) critical thinking and problem solving, artinya, proses pembelajaran hendaknya membuat peserta didik dapat berpikir kritis dengan menghubungkan pembelajaran dengan masalah-masalah kontekstual yang ada dalam kehidupan sehari-hari, 4) creativity and innovation, artinya peserta didik memiliki kemampuan untuk mengembangkan, menyampaikan gagasan baru kepada orang lain, bersikap terbuka dan responsif terhadap perspektif baru dan berbeda.

Keempat kecakapan tersebut harus ada dalam proses pembelajaran yang memberikan suatu pemahaman konsep yang mudah dipahami terhadap materi yang dipelajari sehingga berpengaruh terhadap meningkatkan hasil belajar. Rotherdam \& Wilingham (dalam zulyah, 2013:1) mencatat bahwa, "Kesuksesan seorang peserta didik tergantung pada kecakapan abad 21, sehingga peserta didik harus belajar untuk memilikinya. Salah satu model pembelajaran yang dipandang mampu mempengaruhi tingkat kemampuan hasil belajar matematika sesuai tuntutan pembelajaran abad 21 , student centre, communication, belajar berkelompok dan berpikir kritis dalam memilah informasi yang didapat, adalah penggunan model Inside Outside Circle.

Model Inside Outside Circle adalah salah satu cara mewujudkan pembelajaran aktif, inovatif, kreatif dan menyenangkan. Menurut Kurniasih \& Berlin (2016:93) "model pembelajaran Inside Outside Circle dapat memberikan kesempatan pada siswa untuk bekerjasama dengan sesama dalam suasana gotong royong dan mempunyai banyak kesempatan untuk mengolah informasi dan meningkatkan keterampilan berkomunikasi". Tujuan dari pembelajaran ini adalah melatih siswa dapat aktif dalam proses pembelajaran tidak ada siswa yang pasif yang hanya mendengarkan penjelasan guru namun siswa diajarkan untuk belajar mandiri dan berbicara menyampaikan informasi kepada orang lain, selain itu melatih kedisiplinan dan ketertiban, sehingga dalam proses pembelajaran ini, guru hanya mengawasi dan memberikan masukan untuk mempertegas jawaban siswa.

Selain menggunakan model pembelajaran yang inovatif guru juga bisa mengaitkan materi pembelajaran matematika dengan kearifan lokal yang ada di Bali. Menggunakan kearifan lokal jenis sarana prasarana persembahyangan pada pembelajaran matematika akan menghubungkan materi yang dibelajarkan dengan konteks kehidupan nyata atau konkret dengan mendekatkan pembelajaran matematika dalam kehidupan sehari-hari atau lingkungannya. Sehingga materi pembelajaran dapat lebih mudah untuk dipahami. Selain itu, pembelajaran matematika dengan berorientasi kearifan lokal dapat membekali siswa 
mengenai kebudayaan setempat agar tradisi yang dimiliki tidak punah serta memperdalam nilai-nilai kebudayaan, menanamkan rasa syukur kita kehadapan Tuhan, sehingga selain memperkaya ilmu pengetahuan disisi lain dapat melestarikan kebudayaan itu sendiri.

Melihat beberapa uraian permasalahan tersebut, mulai dari guru yang kurang terampil menggunakan model pembelajaran yang inovatif, dan melihat hasil nilai matematika siswa yang rendah dikarenakan siswa masih kesulitan dalam menangkap materi, selain itu usia anak SD berada pada usia konkret perlu pembelajaran yang nyata dan contoh abstrak yang berkaitan dengan kehidupan sehari-hari, maka guru dituntut untuk bisa menerapkan model pembelajaran yang lebih inovatif agar bisa mencetak generasi yang memiliki potensi dalam menghadapi tantangan era globalisasi yang sedang melanda pendidikan saat ini. Somariasih (2017:3) mengatakan, "disamping dengan model pembelajaran yang sesuai upaya dalam meningkatkan hasil belajar siswa perlu dilakukan upaya dengan mengintegrasikan penerapan model pembelajaran dengan materi berorientasi kearifan lokal". Dengan demikian, kearifan lokal sangat penting dalam proses pembelajaran di kelas yang saat ini dihadapkan dengan era globalisasi agar budaya yang dimiliki tidak punah. Sehingga dapat disimpulkan bahwa, jika model pembelajaran Inside Outside Circle berorientasi kearifan lokal dilaksanakan dengan baik dan benar, akan bisa meningkatkan hasil belajar siswa pada pelajaran matematika.

Adapun tujuan dari penelitian ini adalah untuk mengetahui pengaruh model pembelajaran Inside Outside Circle berorientasi kearifan lokal terhadap hasil belajar matematika pada siswa SD kelas V Gugus I Kecamatan Buleleng.

\section{METODE}

Jenis penelitian ini adalah penelitian ekperimen semu dengan desain penelitian post-test only control group design. Populasi dalam penelitian ini adalah siswa kelas V SD Gugus I Kecamatan Buleleng yang terdiri dari 8 kelas seperti pada Tabel 2.

Tabel 2. Data Jumlah Siswa Kelas V SD Gugus I Kecamatan Buleleng

\begin{tabular}{ccc} 
No. & Nama Sekolah Dasar & Jumlah siswa kelas \\
& & V \\
\hline 1. & SD Negeri 1 Banyuning & 41 \\
2. & SD Negeri 2 Banyuning & 36 \\
3. & SD Negeri 3 Banyuning & 30 \\
4. & SD Negeri 5 Banyuning Kelas VA & 22 \\
5. & SD Negeri 5 Banyuning Kelas VB & 20 \\
6. & SD Negeri 6 Banyuning & 24 \\
7. & SD Negeri 8 Banyuning Kelas VA & 21 \\
8. & SD Negeri 8 Banyuning Kelas VB & 20 \\
\hline & Jumlah \\
\hline
\end{tabular}

Dalam penelitian ini, sampel ditentukan dengan menggunakan group random sampling (Agung, 2017). Sebelum menetapkan sampel penelitian terlebih dahulu dilakuan uji kesetaraan pada masing-masing kelas. Hasil uji kesetaraan diperoleh hasil bahwa seluruh kelas kelas IV SD Gugus IV Kecamatan Susut memiliki kemampuan yang setara. Untuk menentukan kelas eksperimen dan kontrol, peneliti melakukan sistem undian. Hasil undian tersebut IV SD N 3 Abuan dipilih sebagai kelas eksperimen dan IV SD N 2 Susut sebagai kelas kontrol. 
Data pada penelitian ini dikumpulkan dengan beberapa metode pengumpulan data yang disesuaikan dengan permasalahan yang dikaji pada penelitian ini. Sesuai dengan permasalahannya maka data yang diperlukan, yaitu sikap sosial dan hasil belajar IPS. penelitian ini data hasil belajar IPS diperoleh melalui tes objektif dan sikap sosial melalui pemberian kuisioner.

Hasil penelitian ini dianalisis bertahap yaitu: analisis deskriptif dan inferensial. Uji prasyarat yang dilakukan adalah uji normalitas sebaran data, uji homogenitas varians, dan uji korelasi antar variable terikat. Uji normalitas dilakukan untuk meyakinkan bahwa sampel berasar dari populasi yang berdistribusi normal, sehingga uji hipotesis dapat dilakukan. Uji normalitas data dilakukan pada empat kelompok data yaitu: 1) data sikap sosial kelompok eksperimen, 2) data sikap sosial kelompok kontrol, 3) hasil belajar IPS eksperimen dan 4) hasil Belajar IPS kelompok kontrol.

Uji homogenitas dimaksud untuk memperlihatkan bahwa dua atau lebih kelompok data sampel berasal dari populasi yang memiliki varian yang sama, sedangkan uji kolerasi antara variabel terikat diakukan untuk mengetahui apakah apakah kolerasi antar variabel terikat tersebut tinggi atau rendah. Karena, jika antar variable terikat tinggi maka variable terikat tidak dapat dipisahkan, sedangkan jika kolerasi antar variable terikat rendah atau tidak ada kolerasi variabel terikat dalam penelitian ini dapat dipisahkan. Data dianalisis menggunakan uji dengan bantuan SPSS 17.00 for windows pada taraf signifikasi $5 \%$.

\section{HASIL DAN PEMBAHASAN}

Selanjutnya seluruh kelompok dalam populasi tersebut diuji keseteraannya dengan menggunakan uji anava satu jalur. Dengan kriteria apabila Fhitung < Ftabel, sehingga, dapat disimpulkan tidak ada perbedaan rata-rata antara kelompok yang diujikan. Dengan kata lain, semua kelompok memiliki kemampuan yang setara. Data yang digunakan untuk menguji kesetaraan yaitu, nilai ulangan akhir semester ganjil siswa kelas V. Berdasarkan hasil uji kesetaraan yang menggunakan uji anava satu jalur pada taraf signifikansi $5 \%(0,05)$ diperoleh nilai Fhitung sebesar 0,03 sedangkan nilai Ftabel $=2,05$ pada dbantar $=7$ dan dbdalam $=206$ adalah 2,05. Berdasarkan data tersebut terlihat bahwa nilai Fhitung $<$ Ftabel $(0,03<2,05)$, sehingga $\mathrm{H} 0$ dapat diterima dan $\mathrm{H} 1$ ditolak. Jadi tidak terdapat perbedaan yang signifikan hasil ulangan akhir semester ganjil mata pelajaran matematika siswa SD kelas $\mathrm{V}$ di Gugus I Kecamatan Buleleng. Selanjutnya sampel ditentukan dengan menggunakan teknik Group random sampling dipilih dua kelas secara acak yaitu kelas VB SDN 8 Banyuning yang berjumlah 20 orang sebagai kelompok eksperimen dan kelas VA SDN 5 Banyuning yang berjumlah 22 orang sebagai kelompok kontrol. Soewarno (dalam Agung, 2014) mengatakan, Group random sampling digunakan dimana sampel diambil berdasarkan kelas bukan individu.

Pengumpulan data dalam penelitian ini menggunakan tes. Agung (2014:92) mengatakan, metode tes merupakan, "Cara memperoleh data yang berbentuk suatu tugas yang harus dikerjakan seseorang atau kelompok orang yang dites (tastee), dan dari tes dapat menghasilkan suatu skor (interval). Data yang dikumpulkan dalam penelitian ini adalah data hasil belajar matematika siswa kelas V Gugus I Kecamatan Buleleng. Metode tes dilakukan dengan cara memberikan sejumlah soal untuk mengetahui hasil belajar matematika. Data yang dikumpulkan diambil dari hasil post-test siswa kelompok eksperimen dan kelompok kontrol sesudah menerapkan model pembelajaran Inside Outside Circle berorientasi kearifan lokal. 
Instrumen yang digunakan untuk pengumpulan data tentang hasil belajar matematika adalah tes objektif dengan teknik pilihan ganda. Tes objektif berjumlah 30 butir soal. Dengan dilakukannya tes maka akan mengetahui penguasaan siswa terhadap pelajaran matematika yang mereka peroleh selama penelitian. Setiap soal disertai dengan empat alternatif jawaban yang bisa dipilih oleh siswa (alternatif a, b, c, dan d). Setiap item akan diberikan skor 1 apabila siswa dapat menjawab dengan benar (jawaban dicocokan dengan kunci jawaban) dan akan mendapat skor 0 apabila siswa salah dalam menjawab. Skor setiap jawaban akan dijumlahkan dan jumlah skor tersebut merupakan skor variabel hasil belajar matematika. Sebelum instrumen digunakan, terlebih dahulu dilakukan uji pakar untuk melihat kualitas isi dari instrumen, kemudian instrument diujikan ke beberapa orang siswa untuk mementukan validitas tiap butir soal yang akan diuji dengan menggunakan korelasi Point Biserial, uji reliabilitas menggunakan KR-20, uji tingkat kesukaran, dan diuji daya bedanya. Berdasarkan hasil uji coba intrumen, diperoleh dari 35 soal yang diujikan terdapat 30 soal yang valid, dan akan digunakan sebagai instrumen post-test.

Data yang diperoleh dari penelitian ini adalah data kuantitatif berupa skor hasil belajar matematika siswa kelas V. Sebelum melakukan pengujian hipotesis, terlebih dahulu dilakukan uji prasyarat yaitu uji normalitas dan uji homogenitas. Pengujian normalitas sebaran data dilakukan dengan Uji Chi-Square. Nilai hitung dibandingkan dengan nilai tabel pada taraf signifikan $5 \%$. Jika nilai hitung lebih kecil dari nilai tabel maka hipotesis nol yang menyatakan bahwa data berasal dari populasi yang berdistribusi normal dapat diterima. Pengujian homogenitas data dilakukan dengan Uji F. Nilai Fhitung dibandingkan dengan Ftabel pada taraf signifikan 5\%. Jika Fhitung < Ftabel maka Ho diterima sehingga dapat disimpulkan bahwa varians data homogen. Pengujian hipotesis dilakukan denggan menggunakan uji-t independent. kriteria pengujian adalah tolak $\mathrm{H} 0$ jika thitung<ttabel, pada taraf signifikansi $5 \%$ dengan $\mathrm{db}=\mathrm{n} 1+\mathrm{n} 2-2$.

Data yang diperoleh dari hasil penelitian ini adalah data hasil belajar matematika siswa pada kelas kontrol dan siswa pada kelas eksperimen yang diperoleh dari hasil pemberian post-test. Pada tabel 3 berikut akan disajikan rangkuman hasil analisis deksriptif, skor hasil belajar siswa pada kelompok eksperimen dan kelompok kontrol.

Tabel 3. Rangkuman Hasil Analisis Deskritif Skor Hasil Belajar Matematika

\begin{tabular}{ccc}
\hline Variabel & Kelas Eksperimen & Kelas Kontrol \\
N & 20 & 22 \\
Mean & 24,05 & 12,23 \\
Median & 24,50 & 11,5 \\
Modus & 25,07 & 10,83 \\
varians & 6,37 & 7,14 \\
Standar deviasi & 2,52 & 2,67 \\
Jangkauan & 10 & 10 \\
Maksimum & 28 & 17 \\
Minimum & 19 & 8 \\
\hline
\end{tabular}

Berdasarkan analisis deskritif data, terlihat bahwa skor hasil belajar matematika siswa pada kelas eksperimen lebih tinggi daripada rata-rata skor hasil belajar matematika siswa kelas kontrol. Sehingga berdasarkan analisis deskritif terdapat perbedaan rata-rata hasil belajar siswa antara kedua kelompok kelas. Sebelum melakukan pengujian hipotesis dengan menggunakan uji-t independent, data yang diperoleh terlebih dahulu dilakukan uji 
Gusti Ayu Novi Ariasih, I Made Suarjana, Gede Wira Bayu. (2018). Jurnal Pendidikan Multikultural Indonesia. Vol. 1 (1) pp. 28-39.

normalitasnya. Hasil pengujian normalitas data hasil belajar matematika pada kelas kontrol dan eksperimen dapat dilihat pada tabel 4 berikut.

Tabel 4. Rangkuman Hasil Uji Normalitasi Data Hasil Belajar

\begin{tabular}{ccccc}
\hline No. & $\begin{array}{c}\text { Kelompok Data Hasil Belajar } \\
\text { Matematika }\end{array}$ & $\chi^{2}$ hitung & $\chi^{2}$ tabel & Status \\
\hline 1 & Post-test Eksperimen & 1,42 & 11,07 & Normal \\
\hline 2 & Post-test Kontrol & 1,97 & 11,07 & Normal \\
\hline
\end{tabular}

Kriteria pengujian, jika $\chi^{2}{ }_{h i t}<\chi^{2}{ }_{t a b}$ dengan taraf signifikasi $5 \%$ (dk = jumlah kelas dikurangi parameter, dikurangi 1), maka data berdistribusi normal. Sedangkan, jika $\chi^{2}{ }_{h i t} \geq \chi^{2}{ }_{t a b}$, maka sebaran data tidak berdistribusi normal. Berdasarkan hasil perhitungan degan menggunakan rumus Chi-Square, diperoleh data hasil post-test kelompok eksperimen dan kontrol berdistribusi normal.

Selanjutnya akan dilakukan uji homogenitas varians. Uji homogenitas varians antar kelompok bertujuan untuk memeriksa kesamaan varians antar kelompok perlakuan. Dalam penelitian ini, uji homogenitas dilakukan terhadap varians pasangan antar kelompok eksperimen dan kontrol. Uji yang digunakan adalah uji-F dengan kriteria data homogen jika $\mathrm{F}_{\text {hit }}<\mathrm{F}_{\text {tab. }}$.

Rekapitulasi hasil uji homogenitas varians antar kelompok eksperimen dan kontrol disajikan pada tabel 5 berikut.

Tabel 5. Rangkuman Hail Uji Homogenitad Varians

\begin{tabular}{cccc}
\hline Data & $\mathbf{F}_{\text {hitung }}$ & $\mathbf{F}_{\text {tabel }}$ & Kesimpulan \\
\hline $\begin{array}{c}\text { Post-Test Kelompok Eksperimen dan Kelompok } \\
\text { Kontrol }\end{array}$ & 1,12 & 2,13 & Homogen \\
\hline
\end{tabular}

Berdasarkan tabel 5, diketahui $F_{\text {hit }}$ hasil kelompok eksperimen dan kontrol adalah 1,12 sedangkan $\mathrm{F}_{\text {tab }}$ pada $\mathrm{db}_{\text {pembilang }}=19, \mathrm{db}_{\text {penyebut }}=21$, dan taraf signifikansi $5 \%$ adalah 2,13. Hal ini berarti, varians data hasil belajar matematika kelompok eksperimen dan kontrol adalah homogen.

Setelah pengujian prasyarat terpenuhi selanjutnya dilakukan pengujian hipotesis penelitian $\left(\mathrm{H}_{1}\right)$ dan hipotesis nol $\left(\mathrm{H}_{0}\right)$. Rumusan hipotesisnya sebagai berikut:

$\mathrm{H}_{0} \quad$ : Tidak terdapat pengaruh yang signifikan model pembelajaran Inside Outside Circle berorientasi kearifan lokal terhadap hasil belajar matematika pada siswa SD kelas V Gugus I Kecamatan Buleleng.

$\mathrm{H}_{1} \quad$ : Terdapat pengaruh yang signifikan model pembelajaran Inside Outside Circle berorientasi kearifan lokal terhadap hasil belajar matematika pada siswa SD kelas V Gugus I Kecamatan Buleleng.

Jika terbukti bahwa kedua sampel berdistribusi normal dan berasal dari populasi dengan variasi yang homogen, maka dipergunakan analisis uji-t ( $t$-test) dengan taraf signifikansi $5 \%$ dengan rumus penelitian empiris karena $n 1 \neq n 2$. Kriteria pengujian jika $\mathrm{H}_{0}$ 
ditolak dan $\mathrm{H}_{1}$ diterima ini berarti terdapat pengaruh yang signifikan. Tetapi jika $\mathrm{H}_{0}$ diterima dan $\mathrm{H}_{1}$ ditolak ini berarti tidak terdapat pengaruh yang signifikan. Pengujian dilakukan dengan taraf signifikansi $5 \%$ dengan derajat kebebasan $\mathrm{dk}=\mathrm{n}_{1}+\mathrm{n}_{2}-2$. Rangkuman hasil analisis uji-t ditampilkan pada tabel 6 berikut.

Tabel 6. Rangkuman Hasil Uji Hipotesisi

\begin{tabular}{|c|c|c|c|c|c|}
\hline Kelompok & $\mathbf{N}$ & $\mathrm{Db}$ & Mean & $t_{\text {hit }}$ & $t_{\mathrm{tab}}$ \\
\hline Eksperimen & 20 & \multirow{2}{*}{40} & 24,05 & \multirow{2}{*}{6,40} & \multirow{2}{*}{2,021} \\
\hline Kontrol & 22 & & 12,23 & & \\
\hline
\end{tabular}

Berdasarkan tabel 6 , dapat diketahui $t_{\text {hitung }}=6,40$ dan $\mathrm{t}_{\text {tabel }}=2,021$ untuk $\mathrm{db}=40$ pada taraf signifikansi $5 \%$. Berdasarkan kriteria pengujian, karena $t_{\text {hitung }}>t_{\text {tabel }}$ maka $\mathrm{H}_{0}$ ditolak dan $\mathrm{H}_{1}$ diterima. Artinya, terdapat pengaruh yang signifikan model pembelajaran Inside Outside Circle berorientasi kearifan lokal terhadap hasil belajar matematika siswa SD kelas V Gugus I Kecamatan Buleleng.

Berdasarkan analisis hasil penelitian, dapat diketahui terdapat pengaruh yang signifikan model pembelajaran Inside Outside Circle berorientasi kearifan lokal terhadap hasil belajar matematika pada siswa SD kelas V Gugus I Kecamatan Buleleng. Hal ini dilihat dari ratarata hasil belajar matematika siswa dan hasil uji-t. Dapat dilihat bahwa hasil rata-rata siswa menggunakan model pembelajaran Inside Outside Circle berorientasi kearifan lokal adalah 24,05 sedangkan hasil belajar matematika siswa yang dibelajarakan dengan tidak menggunakan model Inside Outside Circle berorientasi kearifan lokal adalah 12,23 selanjutnya hasil penelitian pada uji-t menujukkan bahwa $t_{-h i t u n g}=6,40$ dan $t_{\text {tabel }}=2,021$. Pada taraf signifikansi $5 \%$ pada hasil perhitungan uji-t tersebut bahwa $t_{\text {hitung }}$ lebih besar dari $t_{\text {tabel }}$ dengan demikian hal ini mengadung arti bahwa siswa yang dibelajarkan menggunakan model pembelajaran Inside Outside Circle berorientasi kearifan lokal hasil belajar pada ranah kognitifnya lebih baik dari pada siswa yang tidak mengikuti model pembelajaran Inside Outside Circle berorientasi kearifan lokal.

Hal ini disebabkan karena model pembelajaran Inside Outside Circle berorientasi kearifan lokal merupakan model pembelajaran yang secara penuh mengajak siswa terlibat aktif dalam proses pembelajaran. Model Pembelajaran ini menepatkan siswa dalam kondisi sebagai pencari informasi dan sumber informasi memberikan sebuah proses pembelajaran yang menyenangkan bagi siswa, karena dengan berorientasi kearifan lokal siswa dapat menghadirkan sumber belajar yang secara langsung dapat ditemukan dalam kehidupan sehari-hari sehingga membantu penerapan model pembelajaran ini. Model pembelajaran Inside Outside Circle adalah adanya struktur yang jelas dan memungkinkan siswa untuk berbagi dengan pasangan yang berbeda dengan singkat dan teratur. Selain itu, siswa bekerja dengan sesama siswa dalam suasana gotong-royong dan mempunyai banyak kesempatan untuk mengolah informasi dan meningkatkan keterampilan berkomunikasi. Hal ini diperkuat pendapat Antari (2016) mengatakan, "penerapan teknik Inside Outside Circle dalam pembelajaran mampu memberikan kesempatan siswa untuk membangun pengetahuan berdasarkan pengalaman nyata yang dimiliki oleh siswa, sehingga pembelajaran lebih aktif". selain itu, Anita Lie, (2008:65) mengatakan, "model pembelajaran kooperatif tipe Inside Outside Circle ini bisa digunakan untuk semua tingkat usia anak didik"

Kenyataan ini didukung dari temuan dilapangan selama proses pembelajaran menggunakan model pembelajaran Inside Outside Circle berorientasi kearifan lokal pada tahap mempelajari materi dengan cara berkelompok. Guru mengarahkan siswa untuk 
membentuk kelompok secara heterogen. Guru memberikan topik kepada masing-masing kelompok. Siswa terlihat senang mengikuti pembelajaran secara berkelompok, dengan berkelompok siswa lebih mudah dalam menyelesaikan permasalahan karena adanya interaksi dengan anggota kelompoknya sehingga dapat meningkatkan hasil belajar siswa. Pembelajaran ini membuat siswa antusias bekerjasama dengan kelompoknya untuk saling berbagi informasi. Hal tersebut diperkuat oleh pendapat Dayantari (2013) mengatakan, "pembelajaran yang dilakukan berkelompok siswa akan mudah menemukan dan memahami konsep yang sulit jika mereka saling berdiskusi dengan temannya". Siswa akan secara rutin bekerja dalam kelompok untuk saling membantu memecahkan masalah-masalah dalam pembelajaran.

Pada tahap Pertukaran informasi lingkaran kecil dan lingkaran besar pada saat tahap ini terlihat siswa aktif berbicara berbagi informasi yang mereka pahami kepada temannya siswa juga terlihat menjadi lebih mudah dalam bekerjasama dalam menyelesaikan masalah yang ada karena, siswa sudah banyak mendapatkan informasi yang berbeda-beda dan beragam dengan waktu yang bersamaan, sehingga banyak kesempatan siswa untuk mengolah infpormasi. Hal tersebut akan menyebabkan banyak ide-ide yang muncul dan siswa memiliki pengetahuan yang lebih luas tentang materi yang disajikan. Hal tersebut diperkuat oleh pendapat Susanti (2017:3) model Inside Outside Circle " siswa akan lebih paham apabila berbagi informasi dengan teman sejawatnya." Apabila siswa berkomunikasi dengan siswa lain akan lebih mudah dimengerti atau dipahami.

Dalam model Inside Outside Circle diorientasikan kearifan lokal merupakan model pembelajaran yang dilaksanakan dengan mengaitkan materi dengan kearifan lokal Bali, seperti memberikan permasalahan yang nyata berkaitan pemecahan masalah dalam kehidupan sehari-hari. Materi yang digunakan yaitu volume bangun ruang kubus dan volume balok, sehingga kearifan lokal yang digunakan dalam proses pembelajaran adalah sokasi, sokasi tempat bunga, dan canang ceper berpengaruh positif terhadap hasil belajar kognitif matematika siswa. Temuan dalam penelitian ini siswa terlihat memiliki semangat dan minat yang tinggi dalam mengikuti pelajaran, terbukti ketika diberikan permasalahan dalam LKPD yang berkaitan dengan kearifan lokal siswa lebih mudah memahami dan antusias dalam memecahkan masalah. Hal ini memungkinkan siswa untuk menemukan jawaban sendiri sesuai dengan masalah yang ada berdasarkan pengalaman dialaminya. Menurut Hartoyo (2012:16) mengatakan, "sangat penting agar konsep-konsep matematika yang terdapat dalam kebudayaan-kebudayaan saat ini digali sehingga konsep tersebut dapat membantu siswa dalam mempelajari matematika di sekolah".

Model Inside Outside Circle berorientasi kearifan lokal berpengaruh terhadap hasil belajar matematika, karena mdel pembelajaran Inside Outside Circle memiliki beberapa kelebihan. Shoimin (2014) mengatakan, kelebihan yang dimiliki model Inside Outside Circle adalah, (1) tidak ada bahan spesifikasi yang dibutuhkan untuk strategi sehingga dapat dengan mudah dimasukkan ke dalam pelajaran, (2) kegiatan ini dapat membangun sifat kerjasama antar siswa, (3) mendapat informasi yang berbeda pada saat bersamaan. Dibelajarkan dengan berorientasi kearifan lokal dapat meningkatkan minat dan perhatian sehingga siswa mudah memahami materi sehingga berdampak baik dalam meningkatkan hasil belajarnya. Selain itu, siswa dapat menambah wawasan dan mempelajari budaya setempat sehingga mampu melestarikan budaya lokal.

Jadi dalam proses pembelajaran guru tidak harus membatasi materi yang akan diberikan kepada siswa sehingga penerapan model pembelajaran Inside Outside Circle dapat diterapkan secara efektif. Penelitian ini sejalan dengan hasil penelitian tentang penerapan 
model pembelajaran Inside Outside Circle. Pertama penelitian yang dilakukan oleh Megawati (2014) menyatakan, terdapat perbedaan hasil belajar IPA antara kelompok siswa yang belajar menggunakan model Inside Outside Circle dan kelompok siswa yang belajar dengan menggunakan model konvensional pada siswa kelas $\mathrm{V}$ di gugus VII Kecamatan Sawan diperoleh berdasarkan $t_{\text {hitung }}(14,49)>t_{\text {tabel }}(2,007)$. Kedua penelitian serupa juga dilaksanakan Dewi Antari (2016) hasil penelitian menunjukkan terjadi peningkatan persentase motivasi belajar dan pemahaman konsep IPA pada siswa kelas IV semester II di SD 1 Serampingan, kecamatan Selemadeg tahun 2015/2016 yang diperoleh rata-rata motivasi belajar siswa sebesar $88,7 \%$ (tinggi) dan rata-rata pemahaman konsep IPA siswa sebesar $88,4 \%$ (tinggi). Oleh karena itu, hasil penelitian tersebut berhasil memperkuat penelitian ini tentang penerapan model pembelajaran Inside Outside Circle.

Berbeda dengan pembelajaran matematika yang tidak menggunakan model Inside Outside Circle menunjukkan bahwa dalam proses pembelajaran siswa lebih banyak belajar matematika secara prosedural, pembelajaran tradisional atau disebut juga dengan metode ceramah, karena sejak dulu metode ini telah dipergunakkan sebagai alat komunikasi lisan antara guru dengan anak didik dalam proses belajar dan mengajar. Dalam hal ini, terlihat bahwa pembelajaran kurang maksimal dalam meningkatkan hasil belajar siswa, guru lebih banyak mendominasi kegiatan pembelajaran. Siswa berperan sebagai pendengar yang pasif dan mengerjakan apa yang disuruh guru serta melakukannya sesuai dengan yang dicontohkan. Masalah-masalah matematika yang kontekstual biasanyan digunakan untuk menguji pemahaman siswa pada konsep yang telah dipelajari dan biasanya diberikan pada akhir pembahasan materi antar siswa sangat jarang terjadi interaksi. Selain itu, siswa jarang diberikan kesempatan untuk melakukan eksplorasi terhadap suatu masalah dengan cara pikirnya sendiri. Pembelajaran seperti itu membuat siswa jenuh, kurang inisiatif dan selalu bergantung pada guru.

\section{SIMPULAN}

Berdasarkan hasil penelitian hasil penelitian, terdapat pengaruh yang signifikan hasil belajar matematika kelompok siswa yang mengikuti model pembelajaran Inside Outside Circle berorientasi kearifan lokal dengan kelompok siswa yang tidak mengikuti model pembelajaran Inside Outside Circle berorientasi kearifan lokal pada siswa SD kelas $\mathrm{V}$ gugus I Kecamatan Buleleng. Hasil pengujian hipotesis menunjukkan bahwa Thitung $(6,40)$ lebih besar daripada ttabel $(2,021)$ (Thitung $>$ ttabel) yang diuji pada taraf signifikansi $5 \%$ dengan $\mathrm{db}$ 40. Dengan demikian dapat disimpulkan bahwa terdapat pengaruh yang signifikan model pembelajaran Inside Outside Circle berorientasi kearifan lokal terhadap hasil belajar matematika siswa SD kelas V di Gugus I Kecamatan Buleleng.

Adapun saran yang dapat disampaikan berdasarkan penelitian yang telah dilakukan adalah (1) kepada siswa, dalam pembelajaran hendaknya siswa selalu aktif mengkontruksi pengetahuannya melalui pengalaman sendiri sehingga dapat meningkatkanhasil belajar dan mudah memahami materi yang dipelajarinya, (2) kepada guru, dalam melaksanakan pembelajaran matematika khususnya pembelajaran memecahkan masalah untuk meningkatkan kemampuan hasil belajar siswa guru hendaknya lebih mengkreasikan pembelajaran dengan cara menerapkan model-model pembelajaran yang inovatif, salah satunya adalah model Inside Outside Circle yang didukung berorientasi kearifan lokal yaitu pembelajaran yang relevan untuk dapat meningkatkan hasil belajar siswa karena telah terbukti pada penelitian ini bahwa terdapat pengaruh yang signifikan model pembelajaran Inside Outside Circle berorientasi kearifan lokal terhadap hasil belajar matematika siswa, 
(3) kepada kepala sekolah, kepala sekolah hendaknya mampu mengambil kebijakankebijakan dalam upaya meningkatkan kualitas pembelajaran melalui mengikutsertakan guru dalam seminar atau pelatihan mengenai pembelajaran dalam upaya meningkatkan hasil belajar siswa, (4) kepada peneliti lain, kepada peneliti lain yang ingin melakukan penelitian tentang kemampuan hasil belajar, hendaknya melakukan tes prasyarat untuk mengetahui kemampuan awal siswa. Hal tersebut dapat dilakukan dengan melakukan kordinasi kepada kepala sekolah atau guru di tempat dilakukannya penelitian.

Daftar Pustaka

Agung, A. A. Gede. 2014. Buku Ajar Metodologi Penelitian Pendidikan. Singaraja: Aditya Media Publishing.

Agung, A. A. Gede. 2015. Statistik Inferensial. Singaraja: Undiksha Singaraja

Antari, G. dkk. (2016). "Penerapan Teknik Inside Outside Circle Untuk Meningkatkan Motivasi Belajar dan Pemahaman Konsep IPA Kelas IV". Mimbar Pgsd Undiksha, Volume 4, Nomor 1, (hlm 1-11). Tersedia pada : https://ejournal.undiksha.ac.id/index.php/JJPGSD/article/view/7473. Diakses pada tanggal 30 Januari 2019.

Dayantari, N, dkk. (2013). "Pengaruh Model Pembelajaran Kooperatif Teknik Mencari Pasangan (Make A Match) Terhadap Hasil Belajar IPS Siswa Kelas IV SD". MIMBAR PGSD Undiksha, volume 1, Nomor, 1 Tersedia pada : https://ejournal.undiksha.ac.id/index.php/JJPGSD/article/view/864. Diakses pada tanggal 29 Mei 2019.

Japa, Ngurah \& Suarjana Made. 2014. Pendidikan Matematika 1. Singaraja.

Kemendikbud. 2016. "Peringkat dan capaian PISA Indonesia mengalami peningkatan". Terdapat pada : https://www.kemdikbud.go.id/main/blog/2016/12/peringkat-dancapaian-pisa indonesia-mengalami-peningkatan. Diakses 15 januari 2019.

Kurniasih, Imas dan Berlin Sari. 2016. Ragam Pengembangan Model Pembelajaran Untuk Meningkatkan Profesionalitas Guru. Jakarta : Kata Pena.

Khoeriyah1 \& Mawardi. 2018. "Penerapan Desain Pembelajaran Tematik Integratif Alternatif Berbasis Kearifan Lokal untuk Meningkatkan Hasil dan Kebermaknaan Belajar". Mimbar Sekolah Dasar Volume 5, Nomor 2, (hlm 63 74). Tersedia pada : http: //ejournal.upi.edu/index.php mimbar/article/view/11444/pdf. Diakses pada tanggal 30 Januari 2019.

Lie, Anita, 2002. Cooperative Learning:Mempraktikkan Cooperatif Learning Di RuangRuang Kelas. Jakarta: PT Gramedia Widiasarana.

Megawati, K, dkk. (2014). "Pengaruh Model Pembelajaran Kooperatif Tipe Inside Outside Circle (IOC) Terhadap Hasil Belajar IPA Siswa Kelas V Tahun pelajara 2013/2014 Di Gugus VII KecamatanSawan". MIMBAR PGSD Undiksha, volume 2, Nomor 1. Tersedia pada : https://ejournal.undiksha.ac.id/index.php/JJPGSD/article/view/2450. Diakses pada tanggal 28 februari 2019.

Rafianti, I. dkk. (2018). "Pengembangan Perangkat Pembelajaran Matematika Dalam Mendukung Kemampuan Abad 21". KALAMATIKA Jurnal Pendidikan Matematika, Volume 3, Nomor 2, (hlm.123-138). Tersedia pad http://www.kalamatika.matematika-uhamka.com/index.php/kmk/article/view/137. Diakses pada tanggal 29 Januari 2019. 
Susanto, Ahmad. 2013. Teori Belajar dan Pembelajaran di Sekolah Dasar. Jakarta: Kencana Prenada Media Group.

Susanti, Made Trisna, dkk. "Pengaruh Model Pembelajaran Inside Outside Circle Berbasis Lingkungan Terhadap Hasil Belajar Ipa Siswa Kelas V." MIMBAR PGSD Undiksha 5.2 (2017). Tersedia pada: https://ejournal.undiksha.ac.id/index.php/JJPGSD/article/view/11073. Diakses pada tanggal 20 Mei 2019.

Shoimin, Aris. 2014.68 Model Pem Inivatif dalam Kurikulum 2013.Yogyakarta: Ar-Ruzz Media Indonesia.

Somarasih, dkk. (2017). "Pengaruh Model Pembelajaran Kooperatif Tipe Inside Outside Circle (loc) Berbasis Konsep Tri Kaya Parisudha Terhadap Hasil Belajar Ipa Siswa Kelas V". Mimbar Pgsd Undiksha, Volume 5, Nomor 2. Tersedia pada : https://ejournal.undiksha.ac.id/index.php/JJPGSD/article/view/10931. Diakses pada tanggal 29 Januari 2019.

Hosnan, M. (2014). Pendekatan saintifik dan kontekstual dalam pembelajaran abad 21: Kunci sukses implementasi kurikulum 2013. Ghalia Indonesia.

Hartoyo, A. (2012). "Eksplorasi Etnomatematika Pada Budaya Masyarakat Dayak Perbatasan Indonesia-Malaysia Kabupaten Sanggau Kalbar". Jurnal Penelitian Pendidikan, volume 13, Nomor 1, (hlm.14-23). Tersedia pada: http://jurnal.upi.edu/file/3-agung.pdf. Diakses pada tanggal 30 Februari 2019.

Zulhilyah.2013. "Pengaruh Metode Pembelajaran Creative Problem Solving Terhadap Keterampilan Berpikir Kreatif Dan Komunikasi Dalam Pembelajaran IPS Tugas Akhir". Jurusan Pendidikan Guru Sekolah Dasar. Universitas Pendidikan Indonesia. Tersedia pada : https://id.123dok.com//document/q7woolnz-pengaruh-metodepembeljaaran-creative-problem-solving-terhadap-keterampilan-berpikir-kreatif-dankomunikasi-peserta-didik-dalam-pembelajaran-ips.html. Diakses pada tanggal 19 Januari 2019. 